\title{
Research on the Tax Planning of Small and Micro Enterprises Income Tax from the Perspective of Financial Management
}

\author{
Li XueTing, Yuan Yuan, Zhang Rui \\ School of Accounting, Anhui Wenda University of Information Engineering, Hefei City, Anhui Province, \\ China
}

Keywords: Financial management; small and micro enterprises; tax planning; enterprise income $\operatorname{tax}$

\begin{abstract}
With the implementation of the new tax law and the change of ideas and methods, the scientific and rational development of enterprise income tax planning has become a hot issue for the enterprises and tax workers to study and pay attention to. On the basis of a comprehensive introduction of the concept and basic principles of tax planning, this paper analyzes and expounds the main strategies and methods of tax planning for enterprise income tax under the new tax law.
\end{abstract}

\section{Concept of Tax Planning}

At present, the definition of tax planning is not uniform. It is difficult to find authoritative or comprehensive explanations from textbooks, but their connotations are basically the same. Tax planning refers to the purpose of taxpayers to achieve the purpose of reducing the tax burden and realizing the zero risk of tax. In the scope of the law, the tax planning is made through the planning and arrangement of the operations, investment and financial management in the scope of the law, so as to achieve the purpose of tax saving. Analyzing the above concepts, we can see that tax planning has the following two characteristics: first, it clearly indicates the purpose of tax planning. Tax planning is to achieve two purposes at the same time: lighten the tax burden and achieve zero tax risk. If the enterprise does not reduce the tax burden after carrying out tax planning activities, the tax planning is a failure. However, if the enterprise is reducing the tax burden, the tax risk is greatly improved, and its tax planning activities are not successful; two is the means of tax planning. Tax planning requires the enterprise in the scope of the tax law, through the operation, investment, financial management, organization, transaction and other activities in advance reasonable arrangements.

\section{Basic Principles of Tax Planning}

Tax planning is the tax payer on the basis of fully understanding and mastering the tax policy and regulations. When there are a variety of tax options, the taxpayers deal with the finance and operation with the lowest tax burden. In order to do well in tax planning activities, the following basic principles must be followed:

\subsection{Principles of legality}

Enterprises are required to abide by the laws and regulations of the state when carrying out tax planning. It is embodied in the following aspects: first, tax planning can only be carried out within the scope of tax law; second, tax planning can not violate the state financial and accounting regulations and other economic laws and regulations. In violation of economic laws and regulations, it is not advisable to provide false financial accounting information and information. Third, tax planning must pay close attention to the changes of relevant laws and regulations. Tax planning has strong timeliness, and enterprise tax planning must conform to this change.

\subsection{Principle of planning}

Planning means planning, designing and arranging ahead of schedule. In economic activities, the 
duty of tax is usually lagging, and the value added tax is paid after the transaction of the business. After the income is realized or allocated, the income tax is paid. This objectively provides the possibility of planning ahead for tax payment. In addition, there are many aspects of operation, investment and financial management, and the tax regulations are also targeted. The nature of the taxpayer and the tax object is different, and the tax treatment is often different, which provides the taxpayers with the opportunity to choose the lower tax burden. If business activities have occurred, it is not considered tax planning that taxes should be fixed and tax evasion or tax arrears should be made.

\subsection{Principle of balance}

Tax planning should not only be considered in the overall operation, but also the overall interests of the enterprise. Some people think that tax planning is to reduce the tax payment to the lowest point, and the less the tax is, the better. In fact, in real life, the best plan is not necessarily the lightest tax plan. Because everything has two sides, and risks and interests coexist. The reduction of tax burden is not necessarily equal to the increase of total capital gains, but sometimes leads to a decline in overall corporate returns. Tax planning is the best way to design and choose the largest overall income. In this way, it is not difficult to understand why some foreign enterprises in the special economic zones are in violation of the common sense and transfer the profits to the high tax areas abroad by means of transfer pricing. These enterprises are evading foreign exchange control and pursuing the overall income of the group rather than the lightest tax burden.

\subsection{Purposeful principle}

Tax planning is to achieve three purposes at the same time: the first is to reduce the tax burden absolutely. Low tax burden and low tax burden mean low cost and high capital recovery rate, thereby lighten the tax burden and achieve zero tax risk. If the enterprise does not reduce the tax burden after carrying out tax planning activities, the tax planning is a failure. However, if the enterprise is reducing the tax burden, the tax risk is greatly improved, and its tax planning activities can not be successful; two is the relative tax reduction. The relative reduction of tax burden should be linked to the business performance of enterprises. If a company has a considerable increase in sales this year than last year, in this case, the reduction of absolute numbers does not fully reflect the effect of tax planning. Therefore, the tax burden rate is usually used to measure whether the tax burden is relatively reduced. The tax burden rate refers to the macro tax burden rate. It is of practical significance to transform the macro tax burden rate and enable enterprises to analyze the tax burden by using the tax burden rate, and the three is to delay tax payment. Deferring the time of tax payment and obtaining the income of delayed tax will reflect the means of tax planning. Under the long-term planned economy, the enterprise generally does not care to delay the tax payment, and thinks that through all the methods, the part of the tax should be postponed to the end of the year by the end of the year, and the effect of tax saving can not be achieved. This is not a correct view, because the tax is legally delayed to the end of the year after the end of the year, the enterprise has obtained the value of the tax as a year of use of funds, in this sense, tax planning has also achieved good results.

\section{Main Strategies and Methods of Enterprise Income Tax Planning Under the New Tax Law}

\subsection{The choice of favorable organizational form under the new tax law}

The choice of the company system and the partnership. The new tax law stipulates that individual proprietorship enterprises and partnership enterprises do not pay corporate income tax, and only levy personal income tax on their owners' income. The organizational form of modern enterprises generally includes two kinds: corporate system and partnership system (including sole proprietorship). Our country implements the differential tax system for different enterprise organization forms. The business profit of the company system is paid the company tax in the enterprise tax link. The profit after the tax is allocated to the investor in the form of dividend, and 
the investor has to pay the individual income tax once again. The business profits of partnership enterprises are not paid corporate tax, but only the individual income tax paid by partners. It can be seen that investors can get tax benefits through preferential tax policies. Investors should take all factors into consideration and decide whether to choose partnership or company system.

The choice of the subsidiary and the subsidiary. The establishment of a subsidiary or branch company also has a great impact on the amount of tax payment. The new income tax law is paid by the legal person as a unit. Branches that are not independent legal entities may collect income taxes. That is to say, when an enterprise sets up a branch, the subsidiary company set up can collect taxes, and the subsidiary company with independent legal personality should pay income tax separately. If the establishment of a company in the initial stage is more likely to be in a state of loss, then the establishment of a branch is more favorable, and can reduce the tax burden of the general company.

\subsection{Grasp the provisions of the new tax law for the deduction of items.}

Compared with the original enterprise income tax law, the new enterprise income tax law, in general, the new tax law loosened the standard and scope of the deduction of cost and cost, which made the enterprise expand the space of tax planning. In the process of tax planning, enterprises should grasp these changes so as to better design the tax planning plan.

The regulations on tax payroll have been cancelled. The original tax law adopts a taxable wage system, and the portion of the pre tax wage exceeding the deduction limit shall not be deducted. The new tax law has abolished the regulation, and the real legal wage can be deducted in full.

The deductions of public welfare donation were relaxed. The original tax law stipulates that the public welfare and relief donations of the enterprise shall not exceed $3 \%$ of the annual tax payable, and can be deducted in real terms. The new enterprise income tax law allows the deduction of public welfare relief donations less than $12 \%$ of the total annual profit and deducts the above tax deduction.

The deduction of $\mathrm{R} \& \mathrm{D}$ costs increased. The original tax law stipulates that the $\mathrm{R} \& \mathrm{D}$ expenses of the enterprise can be deducted, and the annual increase of R \& D costs is more than $10 \%$, and the amount of tax payable in the year is $50 \%$ of the actual amount of its actual occurrence. The new tax law abolished the limit of the annual growth rate of $\mathrm{R} \& \mathrm{D}$ costs by more than $10 \%$, which stipulated that the R \& D cost of the enterprise could be deducted by $150 \%$ of the amount of tax payable in the year. On the one hand, it helps enterprises to develop new products and explore new fields; on the other hand, it also embodies the policy orientation of the state supporting scientific research and development and encouraging innovation.

The deduction of advertising costs has been adjusted. The original tax law divides the deduction of advertising expenses into three kinds of cases: high and new technology enterprises are deducted, and the advertising expenses of grain type liquor may not be deducted before tax; the advertising expenses of the general enterprises are deducted according to a certain proportion of the sales income of the same year, and more than the proportion can be transferred to the next year. However, the new tax law does not specify the percentage of deductions for advertising costs. The actual advertising expenses incurred in every year of the enterprise are deducted from the actual conditions, but the new tax law clearly stipulates that the sponsorship expenditure shall not be deducted before tax.

\subsection{Make reasonable use of the provisions on tax preferences in the new tax law.}

The choice of enterprise investment industry. The new tax law stipulates that the high and new technology enterprises that need to be supported by the State shall be subject to enterprise income tax at a tax rate of $15 \%$. The venture capital enterprises invest in the unlisted small and medium high-tech enterprises for more than 2 years (including 2 years), and can deduct the taxable income of the venture capital enterprise according to the $70 \%$ of the investment amount to the small and medium high-tech enterprises, which conforms to the conditions of deductible and can not be deducted at the same year, and can be extended year by year in the future tax year. Continue to deduct. These regulations indicate that the national industrial policy is the development of the high-tech enterprises, and the enterprises should make full use of their own conditions in the 
process of tax planning, which is not only conducive to reducing the tax burden of the enterprises, but also helps to improve the level of science and technology and the ability of scientific and technological innovation and development in China.

The choice of the composition of an enterprise. The new tax law stipulates that the disabled workers arranged by enterprises shall be deducted according to the actual wages paid to disabled workers by $100 \%$. The enterprises should arrange the employment of the disabled workers as many as possible with their own conditions. On the one hand, the disabled workers create profits for the enterprises, on the other hand, it also helps to reduce the tax burden of the enterprises, and also promotes the harmonious and stable development of the whole society.

\subsection{Strategies and methods of tax planning in accounting}

Under the new tax law, it is feasible to make tax planning in different aspects of accounting. Some tax planning methods can not reduce the total tax payment, but can delay the tax time to the next year or the next few years. Due to the time value of money, the deferral of tax time will also bring benefits to enterprises.

Tax planning is made by using different recognition time of sales revenue. There are basically three types of product sales in the enterprise: ready sale, consignment, and payment in advance. The way of selling is divided into ways of buying and selling and collecting fees. There is no difference between the way of buying and selling, and the client should confirm the sales revenue in the current period. In the charge of charges, the principal should not normally confirm the income of the goods sold, and should confirm the sales of the goods when the agent is issued by the trustee. In the form of advance payment, the enterprise usually recognizes the revenue when the goods are issued, and the goods received before it should be recognized as liabilities. Each of these sales methods has its income confirmation conditions, and the enterprise can control the time of revenue recognition by controlling the conditions of the revenue recognition. In the process of income tax planning, enterprises should pay special attention to the sales business near the end of the year, which is the easiest way to plan revenue recognition time.

Use the extraction of bad debt preparation to carry out tax planning. The bad debt preparation for the bad debt loss is the only special item in the accounting system "the eight reduction preparation", which can be set up with certain conditions and standards before tax in accordance with the tax law. It is the content that can not be ignored in the tax planning of enterprise income tax. In carrying out tax planning, we should pay attention to the following differences between the accounting system and the tax law: (1) the range of provision for bad debts is different. The current accounting system stipulates that the provision for provision for bad debts includes accounts receivable and other receivables, but does not include notes receivable. The law of tax stipulates that the scope of the preparation for the preparation of bad debts deducted before tax is limited to the amount of accounts receivable, including the amount of bills receivable, due to the sale of goods, products or services. That is to say, the tax law gives the amount of a bill receivable more than the accounting provisions, and the amount of one other receivable less than that of the accounting regulations. (2) the method and ratio of provision for bad debts are different. The accounting system of enterprises stipulates that the method and proportion of provision for bad debts shall be determined by the enterprise itself. The method of extraction can not be changed arbitrarily when it is determined; if necessary, it should be stated in the notes to the accounting statements. The specific methods are: accounts receivable balance percentage method, sales percentage method, age analysis method and so on. The tax law only provides a method, that is, the percentage of accounts receivable percentage, and the proportion of its receivable shall not exceed $0.5 \%$ of the balance of accounts receivable at the end of the year.

Make use of the difference of inventory cost valuation method to carry out tax planning. According to the new tax law, the inventory cost calculated by the enterprise according to the regulations shall be deducted when calculating the taxable income. The new accounting standards stipulate that the enterprise should adopt the advanced first out method, the weighted average method (including the moving weighted average method) or the individual valuation method to 
determine the actual cost of the inventory. That is, the application of the last in first out method should be abolished, and the enterprises should not be allowed to use the last in first out method to confirm the cost of issuing the inventory. According to the current accounting system and the provisions of the tax law, enterprises can choose any pricing method according to their own circumstances. Different inventory cost valuation methods will have different effects on the cost and the total profit of the enterprise, and the amount of income tax will be different.

Tax planning is made by using depreciation methods and years of fixed assets. The depreciation of fixed assets is an important part of the cost. According to the current accounting system of China, the methods of depreciation include the average method of years, the double degressive balance and the sum of years. The amount of depreciation calculated by different depreciation methods is inconsistent, and the cost of the fixed assets allocated to each period is also different, which will eventually affect the size of the enterprise tax burden. The original tax law stipulates that the fixed assets can only be used to extract depreciation by the straight line method (the year average method), while the new tax law stipulates that the fixed assets of the enterprise need to accelerate the depreciation because of the technological progress and so on. It can shorten the depreciation years or take the method of accelerating depreciation. This provides a new space for the enterprise income tax planning.

\section{Acknowledgements}

Key project of Humanities and social science research project of Colleges and universities in Anhui "Research on income tax planning of small and micro profit enterprises based on the perspective of financial management” (SK2017A0719)

\section{References}

[1] Arunkumar, N., Ramkumar, K., Hema, S., Nithya, A., Prakash, P., Kirthika, V. Fuzzy Lyapunov exponent based onset detection of the epileptic seizures[C]//Information \& Communication Technologies. IEEE, 2013:701-706.

[2] Jonathan J. Faig, Alysha Moretti, Laurie B. Joseph, Yingyue Zhang, Mary Joy Nova, Kervin Smith, and Kathryn E. Uhrich. Biodegradable Kojic Acid-Based Polymers: Controlled Delivery of Bioactives for Melanogenesis Inhibition[J]. Biomacromolecules, 2017, 18(2):363-373.

[3] Arunkumar, N., Venkataraman, V., Thivyashree, Lavanya. A moving window approximate entropy based neural network for detecting the onset of epileptic seizures[J]. International Journal of Applied Engineering Research, 2013, 8 (15):1841-1847.

[4] Sun X, Xue Y, Liang C, Wang T, Zhe W, Sun G, Li X, Li X, Liu G. Histamine Induces Bovine Rumen Epithelial Cell Inflammatory Response via NF-kB Pathway[J]. Cellular Physiology \& Biochemistry, 2017, 42(3):1109-1119. 